\title{
C2360, a nuclear protein expressed in human proliferative cytotrophoblasts, is a representative member of a novel protein family with a conserved coiled coil-helix-coiled coil-helix domain ${ }^{2, \text { thist }}$
}

\author{
Bart A. Westerman, ${ }^{a}$ Ankie Poutsma, ${ }^{a}$ Eric A.P. Steegers, ${ }^{b}$ and Cees B.M. Oudejans ${ }^{a}, *$ \\ ${ }^{a}$ Molecular Biology Laboratory, Department of Clinical Chemistry, VU University Medical Center, de Boelelaan 1117, 1081 HV Amsterdam, The Netherlands \\ ${ }^{\mathrm{b}}$ Department of Obstetrics and Gynecology, Erasmus University Medical Center Rotterdam, Rotterdam, The Netherlands
}

Received 16 July 2003; accepted 11 December 2003

Available online 1 February 2004

\begin{abstract}
In this study, we describe the identification of nine novel genes isolated from a unique human first-trimester cDNA library generated from the placental bed. One of these clones, called C2360 and located on chromosome 10q22, was selected as it showed restricted expression in placental bed tissue as well as in JEG3 choriocarcinoma cells with absent expression in adult tissues. We show that the expression is restricted to first-trimester proliferative trophoblasts of the proximal column and show that $\mathrm{C} 2360$ is a nuclear protein. No detectable transactivation potential was observed for different domains of the protein. Secondary structure prediction showed that C2360 is a representative member of a eukaryotic family of proteins with a low conservation at the amino acid level, but with strong conservation at the structural level, sharing the general domain (coiled coil 1)-(helix 1)-(coiled coil 2)-(helix 2), or CHCH domain. Each $\alpha$-helix within this domain contains two cysteine amino acids, and these intrahelical cysteines are separated by nine amino acids ( $\mathrm{C}-\mathrm{X}_{9}-\mathrm{C}$ motif). The fixed position within each helix indicated that both helices could form a hairpin structure stabilized by two interhelical disulfide bonds. Other proteins belonging to the family include estrogen-induced gene 2 and the ethanol-induced 6 protein. The conserved motif was found in yeast, plant, Drosophila, Caenorhabditis elegans, mouse, and human proteins, indicating that the ancestor of this protein family is of eukaryotic origin. These results indicate that $\mathrm{C} 2360$ is a representative member of a multifamily of proteins, sharing a protein domain that is conserved in eukaryotes.

(C) 2003 Elsevier Inc. All rights reserved.
\end{abstract}

Keywords: C2360; Extravillous trophoblast; $\mathrm{CHCH}$ domain; Nuclear protein; Proliferation; Placental bed

From gene targeting experiments, several genes that are essential for placental development and function have been identified $[1,2]$. Recently, as a consequence of cDNA microarray technology, systematic approaches of large-scale genome-wide gene expression analysis have been performed in mouse placental tissues with unexpected results. Specific gene classes [3] as well as new genes [4-6] not detected previously by conventional means were identified. This sets the stage for systematic exploration and monitoring of transcriptome changes during placental development, particularly related to placental dysfunction-related disorders.

is Sequence data from this article have been deposited with the EMBL/ GenBank Data Libraries under Accession No. LOC118487.

tots Supplementary data for this article may be found on ScienceDirect.

* Corresponding author. Fax: +31-20-4443895.

E-mail address: cbm.oudejans@vumc.nl (C.B.M. Oudejans).
However, systematic studies of this kind have been done only for mouse placental development. Applications to human development are hampered by the lack of appropriate tissue samples, particularly for early developmental stages. This is certainly the case for human tissue samples representative of the first-trimester placental bed containing the extravillous trophoblast cells invading the deeper layers of the maternal myometrium of the uterus. Invasion of these cells shares features with invasive and metastatic tumor cells.

A number of regulators have been described as involved in the processes occurring at the proliferative/invasive transition zone during first-trimester human extravillous trophoblast differentiation. We constructed a unique cDNA library of human placental bed tissue enriched for firsttrimester extravillous trophoblasts in various stages of invasion, containing 13,000 clones, and searched for factors that regulate or reflect the processes involved during human 


\begin{tabular}{|c|c|c|c|c|c|c|c|c|c|c|}
\hline Clone & 1786 & 1878 & 1883 & 1897 & 1961 & 2026 & 2321 & 2360 & 2426 & GAPDH \\
\hline & RT/-RT & $R T /-R T$ & RT/ / RT & $R T /-R T$ & $R T /-R T$ & RT/ / RT & $R T /-R T$ & RT/-RT & RT/ / RT & RT/-RT \\
\hline Heart & $=$ & a & -1 & 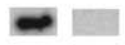 & $=\square$ & 国 & -1 & E & $-a$ & 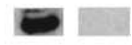 \\
\hline Pancreas & -1 & 0 & -1 & -1 & - & $=1$ & $=$ & 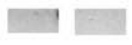 & $=$ & 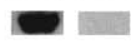 \\
\hline Adrenal Gland & -1 & 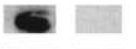 & -1 & $-\square$ & $=-1$ & $=$ & -1 & 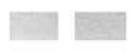 & 6 & $\sigma$ \\
\hline Kidney & 国 & E & $=$ & $=$ & -1 & $=$ & $=$ & 10 & - & - \\
\hline Liver & $=$ & 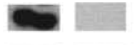 & -1 & -1 & - & Eat & -1 & 四 & 0 & $\infty$ \\
\hline Lung & $=$ & -1 & -1 & -1 & -1 & $=0$ & -1 & Ea & -1 & 0 \\
\hline Embryonal Brain & -1 & - & -1 & -1 & $=$ & -1 & - & $=1$ & - & 0 \\
\hline Vc992 Fibroblasts & $=$ & $-\square$ & $-\square$ & $-\square$ & $-\square$ & 国 & -1 & 페 & -1 & - \\
\hline Full-term Placenta & 6 & 0 & - & e & 0 & 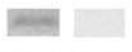 & -1 & 플 & - & 0 \\
\hline t Trimester Placenta & - & - & -1 & e & - & 밈 & - & - & -1 & 0 \\
\hline JEG3 Choriocarcinoma & - & e & 0 & - & - & E & 0 & 0 & -1 & 0 \\
\hline
\end{tabular}

Fig. 1. RT-PCR expression profile of nine genes of the placental bed cDNA library shows that $C 2360$ is strongly expressed in the first-trimester placenta and in the choriocarcinoma cell line JEG3. Weak expression of $C 2360$ is restricted to early development tissues, as observed in embryonic brain, fibroblasts cultured from chorionic villus sample Vc992, and full-term placenta. RT-PCRs are shown on the left and PCR control reactions on the right within each column. All genes are expressed in the first-trimester placenta, except for C2026. Expression analysis of GAPDH was used as an input control. 
placenta development. Here, we report the cloning and identification of a gene called C2360 (LOC118487) that showed strong, nuclear expression in proliferative cytotrophoblasts of the first trimester placenta and which contains a novel protein domain that is representative of a large family of proteins with a conserved structure.

\section{Results}

Identification of nine transcribed chromosomal sequences with unknown organization and function

To identify genes expressed during placental development and in particular during the process of invasion by extravillous human trophoblast cells migrating into the decidual and myometrial parts of the maternal uterus, placental bed tissue at the gestational age of 10 weeks containing all stages of trophoblast invasion was used to construct a cDNA library. Of 268 screened cDNA sequences, nine clones were present that had open reading frames that either did not correspond to known proteins or did not show homology to known proteins. RT-PCR was performed to determine the mRNA expression profile of each of these genes in various tissues, including adult tissues. These results are shown in Fig. 1. Most genes show a broad expression in all tissues. However, one gene, C2360, showed a strong and tissue-restricted expression, with strongest expression observed in the first-trimester placental bed and in the choriocarcinoma cell line JEG3. There were weak bands seen in other developmental tissues, i.e., embryonic brain, chorionic villus fibroblasts, and full-term placenta. The adult tissues heart, pancreas, adrenal gland, kidney, liver, and lung did not show expression of C2360 mRNA.

The gene structure of $C 2360$ showed that $C 2360$ is a triple-exon gene. To determine the $5^{\prime}$ end of the $C 2360$ transcript, the Image clones 2583-g16, 3779-g19, CM1201g06, 10105-j23, and 10720-j15 were sequenced. The sequence of the protein-encoding region is given in Fig. 2. When these experiments were in progress, the gene was annotated by the NCBI under Accession No. LOC118487.

Three-dimensional position-specific scoring matrix (3D-PSSM) analysis shows that C2360 contains a double helical protein motif

Because standard BLAST and Prosite analysis of the C2360 protein did not show homology or the presence of

\section{HUMAN C2360}

\begin{tabular}{|c|c|c|c|c|c|c|}
\hline$\perp$ & ATGGCGACAC & CCAGCCTGCG & GGGTCGTCTG & GCGCGGTTTG & GGAACCCGCG & GAAGCCTGTG \\
\hline 7 & $\mathrm{M}$ & $\underset{\text { Protein }}{\mathrm{P}} \underset{\mathrm{Sinase}}{\mathrm{S}} \mathrm{L}$ ph & $\underset{\text { osphorylation site }}{R} \mathrm{G} \quad \mathrm{R}$ & $\mathrm{R}$ & $\begin{array}{lll}\mathrm{G} & \mathrm{N} & \mathrm{P}\end{array}$ & $\begin{array}{lll}\mathrm{R} & \mathrm{K} & \mathrm{P}\end{array}$ \\
\hline 61 & CTGAAGCCCA & АТАAАССТСТ & САTTCTAGCT & AACCGCGTCG & GGGAGCGGCG & CCGGGAGAAG \\
\hline 21 & K & K & $\mathrm{L}$ & $\mathrm{N} \quad \mathrm{R} \quad \mathrm{V}$ & $\begin{array}{lll}\mathrm{G} & \mathrm{E} & \mathrm{R}\end{array}$ & $\begin{array}{llll}R & R & E & K\end{array}$ \\
\hline 21 & GGCGAGGCGA & СTTGCATCAC & GGAGATGTCG & GTGATGATGG & CTTGCTGGAA & GCAGAATGAA \\
\hline 41 & $\mathrm{G} \quad \mathrm{E}$ & c & $\begin{array}{llll}T & \mathrm{E} & \mathrm{M} & \mathrm{S}\end{array}$ & $\begin{array}{lll}\mathrm{V} & \mathrm{M} & \mathrm{M}\end{array}$ & $\begin{array}{lll}A & \text { C }\end{array}$ & $\begin{array}{llll}K & Q & N & E\end{array}$ \\
\hline & & & Heli & ix 1 & & Coiled \\
\hline 81 & TTCCGCGACG & ATGCGTGCAG & AAAAGAGATC & CAGGGCTTCC & TCGATTGTGC & CGCGAGGGCT \\
\hline 61 & $\begin{array}{lll}F & R & D\end{array}$ & D & $\begin{array}{lll}\mathrm{R} & \mathrm{K} & \mathrm{E}\end{array}$ & Q $\quad G \quad F$ & L $\quad \mathrm{D}$ & A $\mathrm{A}$ \\
\hline & coil regior & n 2 & & Helix 1 & & \\
\hline 41 & CAGGAAGCCC & GAAAGATGAG & ATCAATACAG & GAAACCCTGG & GAGAGTCTGG & GAGTTTAСTT \\
\hline 81 & A & $\mathrm{R} \quad \mathrm{K} \quad \mathrm{M}$ & $\mathrm{R} \quad S \quad I \quad Q$ & $E \quad T \quad L$ & $\begin{array}{lll}G & E & S\end{array}$ & G S L L \\
\hline 301 & ССАAАТАAАТ & TGAATAAGTT & GTTACAGAGG & ТТТССТААСА & ААССТТАССТ & CAGCTGAAAA \\
\hline 101 & K & K & $\mathrm{R}$ & $\mathrm{N}$ & K & $\mathrm{L}$ \\
\hline 36 & GGACAAGTA & TTTTСААТGА & СТGАААТАТА & GCTTCTGACA & ACTATGCAGA & GGCATTTTA \\
\hline 2 & AGACATTGGC & ATTGCCATGC & ССTСTTTGGA & GGGTAGAAGA & GGCAAAACAC & ТTТTТТСАС \\
\hline & GAATC & ATAGTA & & & & \\
\hline
\end{tabular}

Fig. 2. Nucleotide and amino acid sequences of human $\mathrm{C} 2360$. The nucleotide and deduced amino acid sequence numbering is shown on the left side of the sequence. The location of the predicted (coiled coil 1)-(helix 1)-(coiled coil 2)-(helix 2) domain is shown by black (coiled coil) and gray (helix) boxes. The two cysteine amino acids at fixed positions within each helix are highlighted. Three putative phosphorylation sites are indicated in italic. The start and stop codons are shown in boldface. The sequence is available under GenBank Accession No. LOC118487. 
conserved domains on the primary amino acid sequence level, the amino acid sequence was analyzed with the 3DPSSM program. This fold-prediction algorithm predicts the structural folding of the protein and compares them to a representative set of structurally known protein families. This methodology allows detection of proteins or protein domains that share very little sequence similarity by aligning them with sequence profiles that are representative of the diversity of a given multifamily [9]. The protein did not show overt homology to the protein families present in the database.

The secondary structure analysis of the 3D-PSSM program predicted the presence of two centrally located $\alpha$ helical domains separated by a coiled coil domain. Within both helices, two cysteines were identified, each separated by nine amino acids (Fig. 2). This pointed toward a structural conservation, suggesting the presence of a disulfide bond between both helices, which could stabilize a hairpin domain when the helix 2 folds onto helix 1 .
Alternatively, the four cysteines could act as ligands of a metal-binding domain, similar to the domains observed in zinc-finger and related proteins [10].

\section{C2360 is a member of an $\alpha$-helical protein multifamily}

Additional 3D-PSSM structural analysis was therefore performed on weakly similar amino acid sequences from various eukaryotic species. This showed that this structural domain was present in a large number of other proteins, indicating a conserved and potentially important function. An alignment of these related proteins with the predicted conserved domain is given in Fig. 3. Note that each protein contains the conserved cysteines located in both predicted helix regions and each cysteine pair is separated by nine amino acids ( $\mathrm{C}-\mathrm{X}_{9}-\mathrm{C}$ motif). Within each helix, a high occurrence of glutamic acid (E) at position 6 and phenylalanine $(\mathrm{F})$ at position 10 was seen.

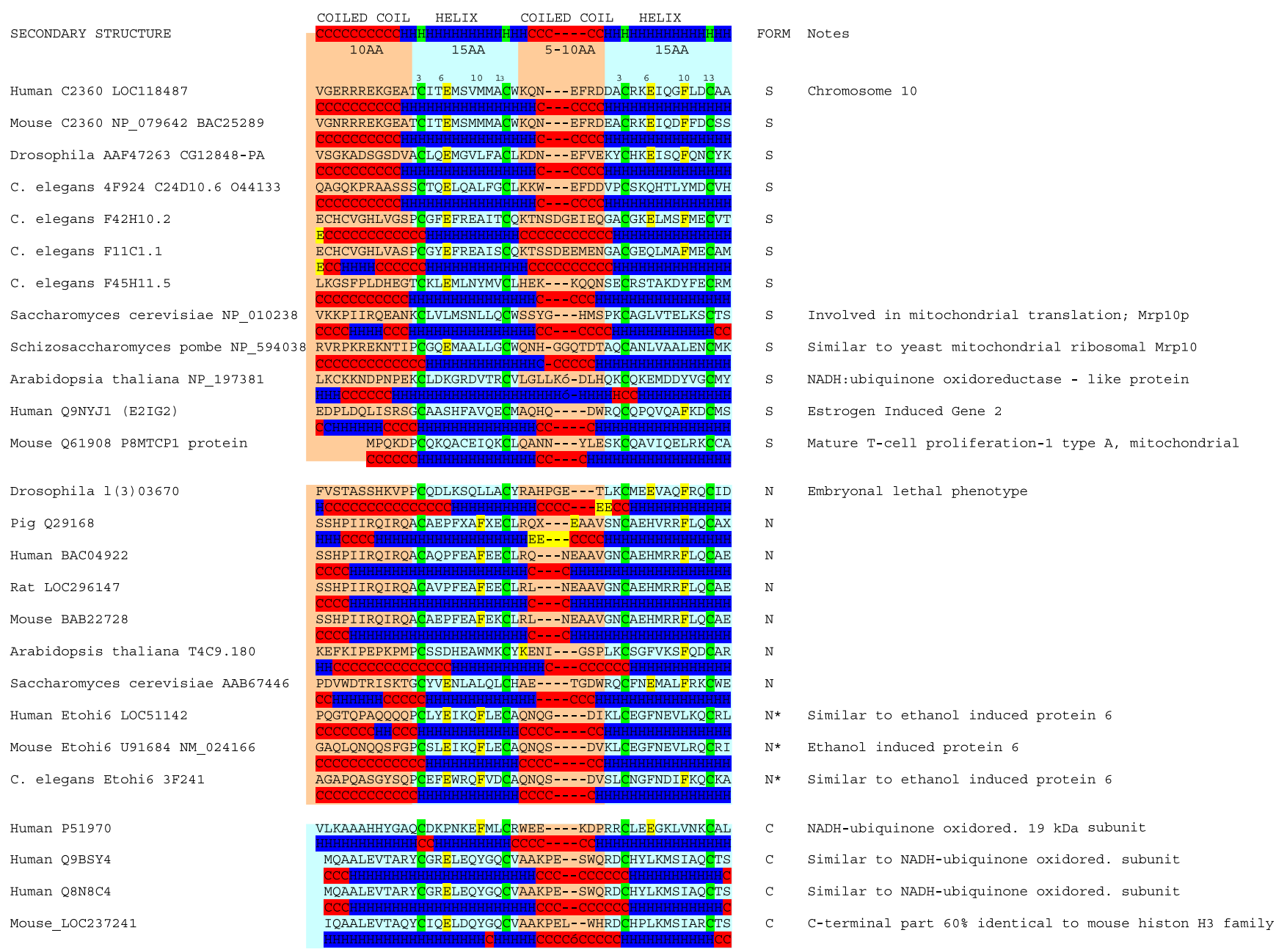

Fig. 3. Alignment of conserved protein domains that have a secondary structure similar to the C2360 protein as predicted by the 3D-PSSM program. The consensus sequence is given at the top. The secondary structure is given below each amino acid sequence. Coiled coil regions (C) are shown in red, helix domain regions $(\mathrm{H})$ are shown in blue, extended sheets (E) are shown in yellow, and conserved cysteine residues (C) are shown in green. The highly occurring amino acids glutamic acid (E), at position 6, and phenylalanine (F), at position 10, within each helix are shown in yellow. Proteins were classified according to the secondary structure and grouped into the subgroups $\mathrm{S}, \mathrm{N}$, and $\mathrm{C}$ (see Discussion for details). The $\mathrm{N}$ group overlaps with the DUF657 PFAM domain and the proteins belonging to the DUF657 group are indicated by asterisks $(*)$. 

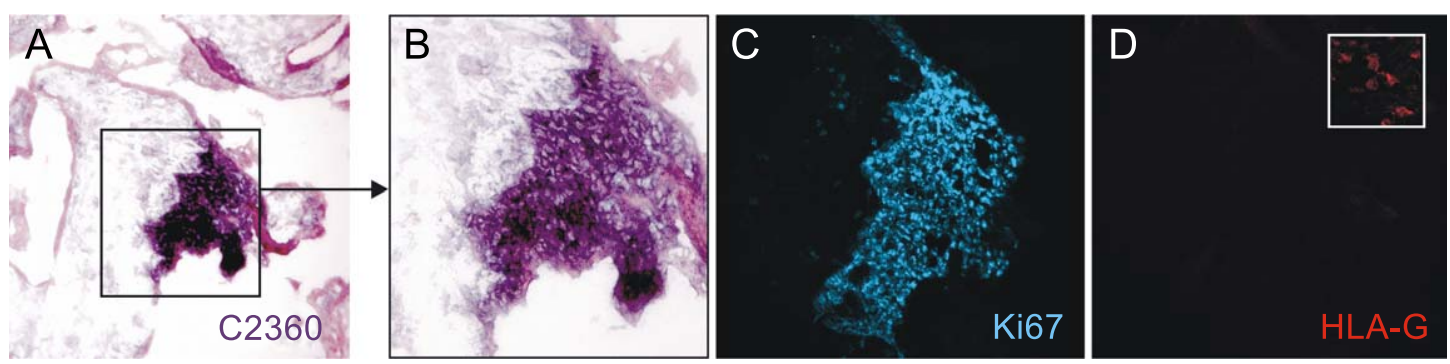

Fig. 4. (A and B) RNA in situ hybridization using C2360 antisense-Dig riboprobes showing that $\mathrm{C} 2360 \mathrm{mRNA}$ is expressed in cytotrophoblasts of the proximal column. (C) Immunostaining with the MIB1 antibody shows that C2360 is expressed in cells that express the proliferation marker Ki67. (D) Immunostaining for HLA-G, a marker of differentiated extravillous trophoblasts, is negative in these proliferative cytotrophoblasts. The inset shows the results of a positive control HLA-G immunostaining.

In addition, two coiled coil regions were predicted. The first coiled coil region, which has a fixed length of 10 amino acids, is located $\mathrm{N}$ terminal of helix 1 . The second coiled coil is present between both helices and possibly acts as a bridge when the helices fold toward each other. This coiled coil region has a variable length of 5 to 10 amino acids. Together these domains form a (coiled coil 1)-(helix 1)-(coiled coil 2)-(helix 2) domain or $\mathrm{CHCH}$ domain. Note that most but not all proteins showed the presence of coiled coil 1 .
The human and mouse C2360 amino acid sequences show $85 \%$ identity in the conserved domain. In Drosophila as well as Caenorhabditis elegans, proteins with a remote homology to $\mathrm{C} 2360$ were observed. The conserved domain of the Drosophila CG12848-PA protein has $46 \%$ identity to the human protein and the $C$. elegans $4 \mathrm{~F} 924$ protein has $30 \%$ identity compared to the human conserved domain. It is yet unclear if these proteins are orthologs. Taken together, these 3D-PSSM data indicate that $\mathrm{C} 2360$ belongs to a group
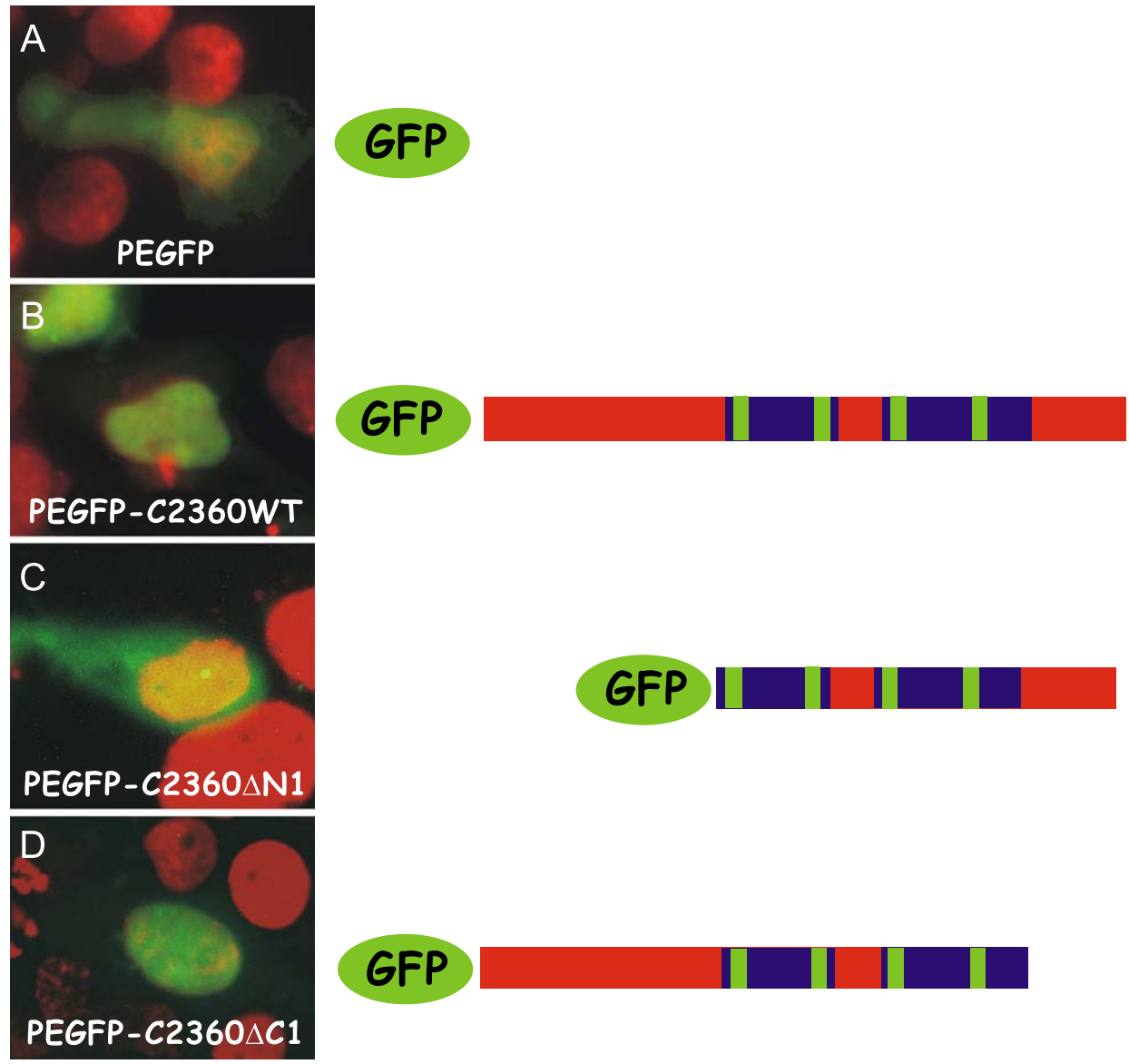

Fig. 5. Transfection of JEG3 with GFP fusion protein constructs showing the intracellular localization of the C2360 protein. The C2360 truncation constructs (indicated on the right) show (B) a nuclear localization for the wild-type protein as well as (D) the C-terminally truncated form. (C) The N-terminally truncated form and (A) GFP show a cytoplasmic localization, showing that the nuclear localization domain of $\mathrm{C} 2360$ resides in the N-terminus of the protein. 
of proteins that have a conserved $\mathrm{CHCH}$ structural backbone with each helix containing a $\mathrm{C}-\mathrm{X}_{9}-\mathrm{C}$ cysteine pair.

\section{C2360 is expressed in proliferative cytotrophoblasts at the proximal zone}

RNA in situ hybridization analysis was performed to analyze the in situ localization of C2360 mRNA in the first trimester placental bed. This showed that the expression was restricted to proliferative cytotrophoblast at the proximal zone of the placental anchoring villi (Fig. 4). Differentiated trophoblasts, both villous and extravillous, showed no expression. There was no expression observed in proliferative cytotrophoblasts located inside the villi, suggesting that C2360 is expressed in a specific subset of proliferative trophoblast cells at the junctional zone of villus to extravillus transition.

\section{Intracellular localization experiments showed that C2360 is a nuclear factor}

Truncation constructs of the $\mathrm{C} 2360$-encoding region fused to eGFP were used to determine the intracellular localization of the protein. The wild-type GFP-C2360WT fusion protein shows a clear nuclear localization (Fig. 5). When the C-terminal region was truncated $(\mathrm{C} 2360 \Delta \mathrm{C} 1)$, this fusion protein also showed a nuclear localization, indicating that the nuclear translocation region resides in the conserved motif or in the N-terminal region. Indeed, when the $\mathrm{N}$-terminal region was truncated $(\mathrm{C} 2360 \Delta \mathrm{N} 1)$, the fusion protein showed a cytoplasmic localization, indicating a putative nuclear localization signal or interacting domain in the N-terminal part of the protein. These results clearly show that C2360 is a nuclear protein with an N-terminally located nuclear localization domain.

\section{C2360 shows no detectable transactivation}

The nuclear localization indicated that $\mathrm{C} 2360$ could be a transcription factor. We analyzed the transactivation potential of the protein by fusing the protein to a DNA-binding protein that recognizes the GAL4 motifs present in a reporter vector. When a transactivation domain is present on the fused protein, this will result in an increase in the basal promoter activity of the reporter vector (principle shown in Fig. 6C). Several truncation constructs (Fig. 6B) were tested for transactivation potential (Fig. 6A) and, although the positive control constructs showed a clear response, no detectable response was observed in the C2360 truncated proteins.

\section{Discussion}

We have identified $\mathrm{C} 2360$ as a nuclear protein that is expressed in proliferative extravillous trophoblast cells of the first-trimester placenta. The small nucleoprotein of 118 aa located on human chromosome 10 has a conserved rodent homolog, and proteins with a remote homology were seen in Drosophila and C. elegans. Based on secondary structure analysis we show that the $\mathrm{C} 2360$ protein is a member of a family of proteins with a low conservation at the amino acid level, but with strong conservation at the structural level with the general domain: (coiled coil 1)(helix 1)-(coiled coil 2)-(helix 2). This domain is called a $\mathrm{CHCH}$ domain. The ancestor of this protein family is likely to be of eukaryotic origin as no homologs have been observed in prokaryotes.

Within this group of proteins containing the $\mathrm{CHCH}$ domain, a classification was made based on the results of the secondary structure analysis. This resulted in the defi-

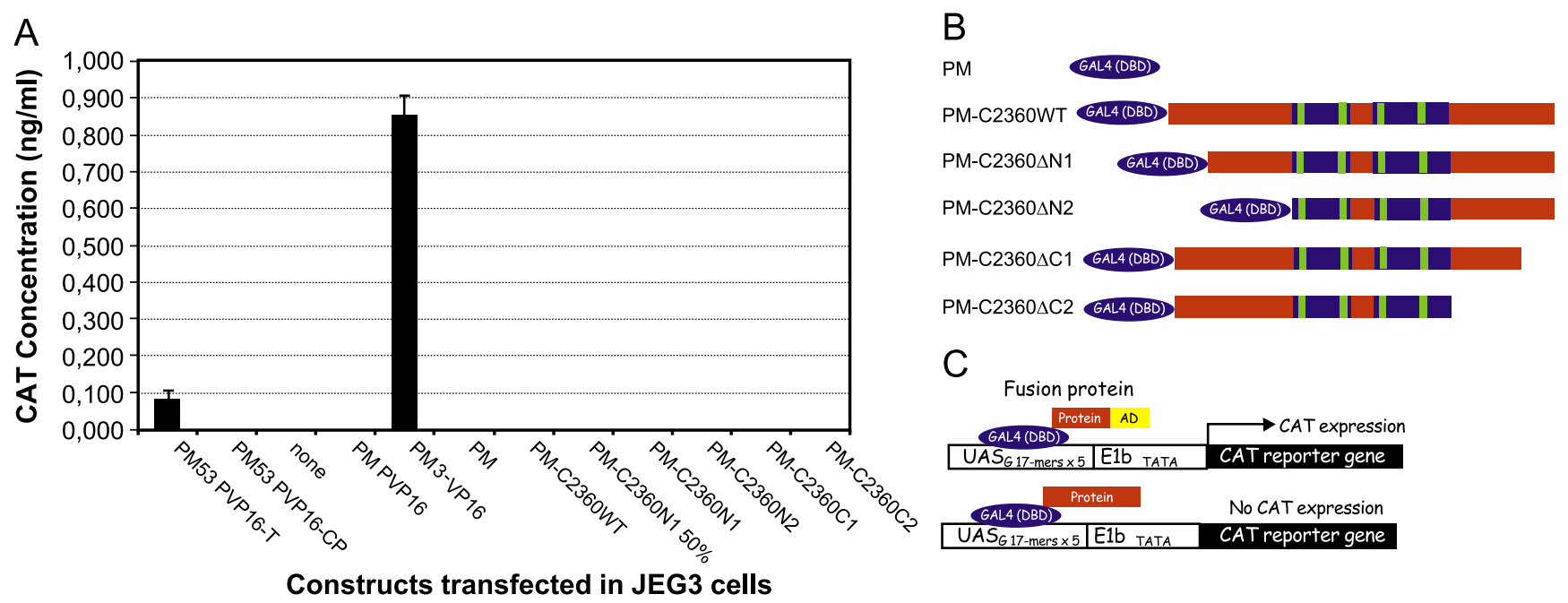

Fig. 6. Transfections of JEG3 cells with C2360-GAL4 DNA binding domain (DBD) fusion protein constructs, showing that the C2360 protein does not have a detectable transactivation activity in this assay. The principle is shown in (C) (see also Results). The transactivation constructs are shown in (B). (A) Positive control experiments show a clear CAT activity. 
nition of three subgroups, the small proteins group, the $\mathrm{N}$ extended group, and the C-extended group, and these are referred to as $\mathrm{S}, \mathrm{N}$, and $\mathrm{C}$ in Fig. 3.

The $\mathrm{S}$ group represents a group of proteins with a small size of 71-164 residues and these proteins have a centrally located $\mathrm{CHCH}$ domain. This group of proteins includes C2360, Mrp10p, estrogen-induced gene 2 (E2IG2) and mature T-cell proliferation-1 type A ( $\left.8^{\mathrm{MTCP} 1}\right)$.

The $\mathrm{N}$ group has an extended $\mathrm{N}$-terminal amino acid region compared to the $\mathrm{S}$ group and the conserved $\mathrm{CHCH}$ domain is located close to the $\mathrm{C}$-terminus. This group includes the ethanol-induced protein 6 and includes homologs of Etohi6, which were grouped into a protein domain designated DUF657 in the Protein Family database (PFAM; Sanger Institute). The PFAM domain contains, in addition to the $\mathrm{C}-\mathrm{X}_{9}-\mathrm{C}$ motif, an additional GXXXGH motif, located $\mathrm{N}$-terminal of the $\mathrm{CHCH}$ domain.

The last group, the $\mathrm{C}$ group, has a different conserved domain, although it has a structural overlap with the $\mathrm{S}$ and $\mathrm{N}$ groups. First, these proteins have a second doublehelix motif, located C-terminal of the conserved doublehelix motif. This motif also contains cysteine pairs in each of both $\alpha$-helices. Second, these proteins lack the predicted N-terminal coiled coil region or have a small coiled coil region. Third, the conserved motif is found close to or at the N-terminus. This distinct group of proteins includes NADH-ubiquinone oxidoreductase subunit proteins [11].

Both helices in the $\mathrm{CHCH}$ domain contain a cysteine pair, and the presence of cysteines at conserved positions within the helices suggests that disulfide bonds connect both helices. Indeed, the $\mathrm{p} 8^{\mathrm{MTCP} 1}$ protein has been investigated by NMR structure analysis and the two helices of the $\mathrm{p} 8^{\mathrm{MTCP} 1}$ protein were shown to be covalently linked by two disulfide bonds, forming an $\alpha$-hairpin, resembling an antiparallel coiled coil $[12-14]$. The $\mathrm{p} 8^{\mathrm{MTCP} 1}$ protein is classified into the $\mathrm{S}$ group in our classification and the other proteins present in this group are expected to have a similar structure. This indicates that the presence of the putative metal binding of the four cysteines as suggested under Results is less likely. A schematic model of this proposed three-dimensional structure is given in Fig. 7. The $\mathrm{C}$ group of proteins is expected to have another threedimensional structure due to the presence of the second double-helix motif.

Our data indicate that $\mathrm{C} 2360$ is a protein that is expressed strongly during early extraembryonic development, as shown for the first-trimester placenta and JEG3 choriocarcinoma cells. Other tissues of early developmental stages, including embryonic brain and extraembryonic fibroblasts cultured from chorionic villus samplings, showed weak bands in the RT-PCR, indicating lower levels of expression. In addition, C2360 is expressed in human embryonic stem cells as well (results not shown). In contrast, all adult tissues screened showed no detectable expression of the transcript. Two other $\mathrm{CHCH}$ proteins, E2IG2 [15] and Etohi6 [16] have been described to respond to estrogen and ethanol,

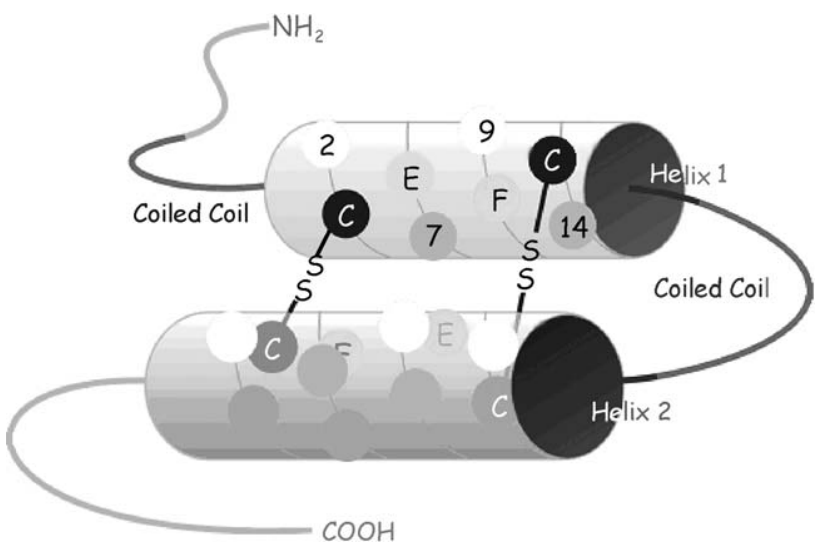

Fig. 7. Model of the predicted structure of the $\mathrm{S}$ group of proteins containing the conserved $\mathrm{CHCH}$ domain as predicted using the 3D-PSSM program. The backbone consists of a 10-amino-acid coiled coil region, followed by two 15 -amino-acid $\alpha$-helices connected by a coiled coil region of 5 to 10 amino acids. Based on the structure of the $\mathrm{p} 8^{\mathrm{MTCP} 1}$ protein [1214], the two $\alpha$-helices are expected to form a hairpin-loop that is stabilized by two disulfide bonds, which are formed by two cysteine pairs that have a fixed position within each helix. Each of these cysteines is separated by 9 amino acids. The highly occurring amino acids glutamic acid (E) and phenylalanine $(\mathrm{F})$ have fixed positions within both helices and reside between both helices in this predicted structure. The two domains flanking the conserved region have a relatively undefined predicted structure, based on 3D-PSSM structure prediction and NMR data in the case of the $\mathrm{p} 8^{\mathrm{MTCP} 1}$ protein [12].

respectively. We tested if estrogen or ethanol induced C2360 transcription; however, no significant upregulation was observed (results not shown).

In Drosophila, the l(3)03670 gene (also called l[3]96601 or $C G 1715-P A)$ encodes a protein that is classified as an Ngroup protein in our classification [17]. This protein showed a broad expression in the embryo with a slightly higher expression in the head. A P-element-introduced homozygous deletion of this gene, l[3]03670, gave a lethal phenotype. The lethal phenotype could be reversed by excision of the $\mathrm{P}$ element [17]. This gene has homologs in humans and mouse (Accession Nos. NP_060282, NP_115719 and AAH16528, BAB24193, NP_079627, respectively). The C. elegans homolog of this gene, called M176.3 (Accession No. NP_496012), showed a 42\% lethality in RNAi experiments of Maeda and co-workers [18] and a wild-type phenotype in RNAi experiments of Kamath and co-workers [19]. Although there might be some variation in penetrance, these results could indicate that this member of the $\mathrm{CHCH}$ family is involved in the progression of developmental processes.

An important question is if the $\mathrm{CHCH}$ motif represents a functional domain in these proteins. In the $\mathrm{p} 8^{\mathrm{MTCP} 1}$ protein, the conserved motif consists of 40 amino acids, while the total protein size is 71 amino acids, showing that the conserved domain represents the majority of the protein. The high occurrence of glutamic acid (E) at position 6 and of phenylalanine $(\mathrm{F})$ at position 10 , each located at fixed positions within each $\alpha$-helix, might indicate that there are functional or structural constraints on the presence of these 
amino acids. The intracellular localization of $\mathrm{CHCH}$ proteins shows variations as were shown for $\mathrm{p} 8^{\mathrm{MTCP} 1}$ (c6.1B) and Mrp10p [20], which have been described as localized to the mitochondria in contrast to $\mathrm{C} 2360$. The $\mathrm{p} 8^{\mathrm{MTCP} 1}$ protein is a putative oncogene that is expressed in T cell prolymphocytic leukemia with $\mathrm{t}(\mathrm{X} ; 14)$ translocations [21,22]. The Mrp10p protein has been described as a mitochondrial ribosomal protein, since it was shown to be associated with a small ribosomal unit when sedimented by centrifugation, suggesting that Mrp10p is associated with the translational machinery [20]. Based on the intracellular localization, these data could suggest that the functions of $\mathrm{CHCH}$ proteins are divergent. We could not detect transactivation potential for the $\mathrm{C} 2360$ protein. However, these results do not rule out the possibility that the protein could act as a transactivator or as a transcriptional repressor. It is a challenge for the future to determine the function of $\mathrm{C} 2360$ as well as the other members of this novel $\mathrm{CHCH}$ family.

\section{Experimental procedures}

\section{Cell culture and tissues}

First-trimester human placental tissue fragments (weeks $6-10$ gestational age) $(n=11)$ were obtained by the Department of Pathology, Section of Human Reproductive Immunology, University of Cambridge from pregnancy terminations. Adult tissues were obtained by the Department of Pathology at the VU University Medical Center (VUMC). The hysterectomy specimen was obtained by E.A.P.S. Term placenta tissues were obtained by the Department of Gynecology of the VUMC. The Department of Cytogenetics of the VUMC obtained chorionic villus samples, used to culture fibroblasts of extraembryonic origin. Tissues were stored frozen at $-70^{\circ} \mathrm{C}$ or in liquid nitrogen. Fibroblasts were maintained in Amniomax medium including supplements (Life Technologies). The choriocarcinoma JEG3 cell line was maintained in Iscove's medium with Glutamax I (Life Technologies) supplemented with 10\% FBS and antibiotics.

\section{Identification of genes}

A previously prepared cDNA library of placental bed tissue from the decidua-myometrium transition zone of a hysterectomy specimen at a gestational age of 10 weeks diagnosed for cervical carcinoma [7] was used to identify novel genes. Sequencing was performed using an ABI 310 genetic analyzer (Perkin-Elmer) using the Big Dye-M13 forward primer for sequencing of plasmid DNA or Big Dye terminator reactions in combination with gene-specific primers for sequencing of Qiagen-purified PCR products. From the library, we selected nine genes that either were not annotated in cDNA libraries of HUGO/Celera databases or could not be classified according to their homology with proteins with known function. To determine the $5^{\prime}$ end of the selected C2360 transcript, Image clones (2583g16, 3779-g19, CM1201-g06, 10105-j23, and 10720-j15) were sequenced.

\section{$m R N A$ expression profile by $R T-P C R$}

The nine selected clones were analyzed for gene structure using the NIX analysis method of HGMP and, based on this analysis, primers were designed (Table 1). Expression analysis of the nine selected genes was performed by RT-PCR using the Superscript II (RNase H negative) OneStep RT-PCR System (Invitrogen). One microgram of total RNA was mixed with forward and reverse primers (50 pmol each) in a total volume of $10 \mu \mathrm{l}$ and heated for $1 \mathrm{~min}$ at $95^{\circ} \mathrm{C}$, followed by immediate cooling on ice. RT-PCR buffer including dNTPs, magnesium sulfate (1.25 mM), betaine (1 M), 7.5 units RNasin (Promega), and 1 $\mu \mathrm{l}$ enzyme mix were added to a total volume of $50 \mu \mathrm{l}$. RT-PCR mixes were subjected to reverse transcription for $30 \mathrm{~min}$ at 50 or $55^{\circ} \mathrm{C}$ (dependent on the GC content of the template), followed by inactivation of RT enzyme at $95^{\circ} \mathrm{C}$ (1 min) and PCR consisting of 35 cycles (denaturation, 1 min at $95^{\circ} \mathrm{C}$; annealing at an appropriate temperature; extension, $2 \min$ at $72^{\circ} \mathrm{C}$ ) with a final extension at $72{ }^{\circ} \mathrm{C}$ for $10 \mathrm{~min}$.

Table 1

Primers used for the RT-PCR expression profile

\begin{tabular}{lll}
\hline Clone & Forward primer $^{\text {a }}$ & Reverse primer \\
\hline 1786 & 5'CCATCCAGCAGAGCCTGCTT-3' & Product size \\
1878 & 5'CAGCCCGTCTTCCGGAATTTCTCAAC-3' & 5-CCCCAAGCTCAGCAGCAGAG-3' \\
1883 & 5'CCTGAGCAAATTCATGATGTTGTACG-3' & 5-CCAGTACATGCAAGGTAAAAACTTGACG-3' \\
1897 & 5'GCCAAGAATTCTCTCACTTAAGCAGGA-3' & 5-GGGCAGGATTGGGGTGTTCA-3' \\
1961 & 5-CCCTCCCCTTTGGTGTGA-3' & 5-AGGCTTTTCCCTAAAGGCCTCTA-3' \\
2026 & 5-CAAGGCCTTCGAGTGTAA-3' & 5-CCCTGGCTTGGACCCTTA-3' \\
2321 & 5'CCGTGCAAATGCCAAAGT-3' & 5-TCTGCCACTTGGGATTTG-3' \\
2360 & 5'CGCGACGATGCGTGCAGA-3' & 5-GGCACAGGTTGCCAAGAG-3' \\
2426 & 5'AGGGCTCTCCGAGCCACGTACC-3' & 5-GGGCATGGCAATGCCAATG-3' \\
GAPDH & 5'CGGAGTCAACGGATTTGGTCGTAT-3' & 5-TCGGGCGGCTAACAGAGGTAGC-3' \\
\hline
\end{tabular}

${ }^{a}$ Each forward primer was chosen in the sense strand. 
Table 2

Primers used for the truncation constructs used in the intracellular localization determination and to identify transactivation domains of C2360

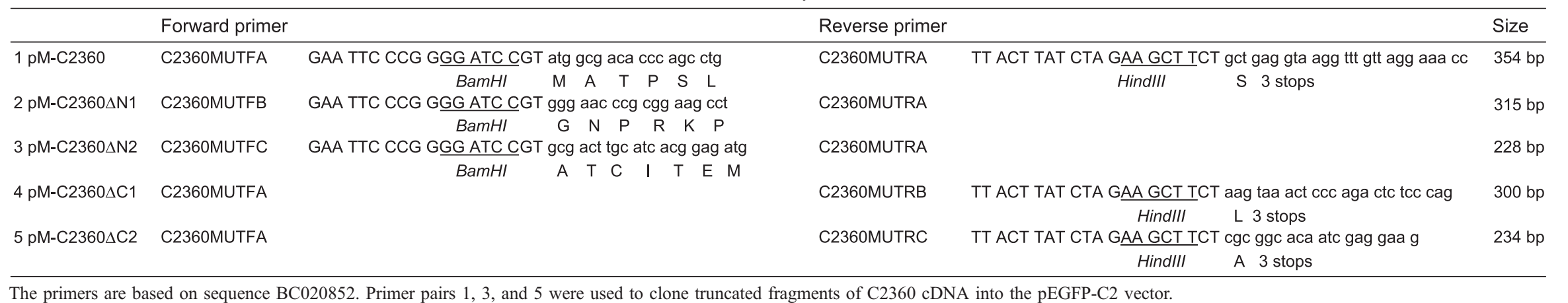

The primers are based on sequence BC020852. Primer pairs 1, 3, and 5 were used to clone truncated fragments of C2360 cDNA into the pEGFP-C2 vector. 
Localization of mRNA expression of C2360 by RNA in situ hybridization

Localization of $C 2360$ mRNA expression in the placental bed was done by RNA in situ hybridization. C2360 cRNA riboprobes were generated by in vitro transcription of a 441bp cDNA fragment, which was amplified with the primers forward- $B g l \mathrm{II}$, 5-GTCCGGACTCAGATCTATGGCGACACCCAGCCTG-3', and reverse-PstI, 5'GTACCGTCGACTGCAGGGCATGGCAATGCCAATG-3', and subsequently cloned into a pGEMT vector (Promega). Antisense cRNA probes were made by linearizing with $N c o$ I and transcribing with SP6 RNA polymerase (Promega). Sense cRNA probes were made by linearizing with NotI and transcribing with T7 RNA polymerase, both in the presence of 25\% DIG-11-UTP.

Cryostat sections were air dried at room temperature and fixed for $20 \mathrm{~min}$ in freshly prepared $4 \%$ paraformaldehyde in phosphate-buffered saline (PBS; $0.9 \mathrm{mM} \mathrm{Na}_{2} \mathrm{HPO}_{4}, 0.17$ $\mathrm{mM} \mathrm{NaH}_{2} \mathrm{PO}_{4}, 150 \mathrm{mM} \mathrm{NaCl}, \mathrm{pH}$ 7.4), rinsed three times for 5 min each in PBS, and rinsed briefly in water. After acetylation for 10 min with $0.25 \%$ acetic anhydride in $1 \%$ triethanolamine and two washing steps in PBS, sections were rinsed in $2 \times$ standard saline citrate $(20 \times$ SSC: $3 \mathrm{M} \mathrm{NaCl}$, $1.55 \mathrm{M}$ sodium citrate, $\mathrm{pH}$ 7.0) for at least $5 \mathrm{~min}$. The slides were prehybridized for $4 \mathrm{~h}$ at room temperature in hybridization buffer containing 50\% formamide, $10 \%$ dextran sulfate, $1 \times$ Denhardt's solution $(50 \times$ Denhardt's: $0.5 \mathrm{~g}$ Ficoll, $0.5 \mathrm{~g}$ polyvinylpyrrolidone, $0.5 \mathrm{~g}$ bovine serum albumin in $50 \mathrm{ml}$ MilliQ water), $0.2 \times \mathrm{SSC}, 500 \mu \mathrm{g} / \mathrm{ml}$ denatured salmon sperm DNA (Roche), and $250 \mu \mathrm{g} / \mathrm{ml}$ tRNA (Sigma). Hybridization was performed using denatured C2360 cRNA riboprobes diluted 1:500 in hybridization buffer, covered with Parafilm, and incubated overnight in a moist chamber at $55^{\circ} \mathrm{C}$. The following day the sections were washed with $5 \times \mathrm{SSC}$ for $5 \mathrm{~min}$, rinsed in $2 \times \mathrm{SSC}$, and washed under high stringency in $0.2 \times \mathrm{SSC}$ in $50 \%$ formamide for $30 \mathrm{~min}$ (all at $55^{\circ} \mathrm{C}$ ), followed by a final wash with $0.2 \times \mathrm{SSC}$ for $5 \mathrm{~min}$ at room temperature. Immunohistochemical detection of immobilized DIG riboprobes was then performed. For this, sections were washed in digoxigenin buffer (DB) (33 mM maleic acid, $50 \mathrm{mM} \mathrm{NaCl}, \mathrm{pH} 7.5)$ (5 min) and blocking solution was added for $1 \mathrm{~h}$ at room temperature (1\% w/v Blocking reagent (Roche) in DB). Anti-DIG-alkaline phosphatase antibody (Roche; 1:5000 dilution in DB) was added after blocking and the sections were incubated for $1.5 \mathrm{~h}$ at room temperature. Sections were washed in DB $(2 \times 15 \mathrm{~min})$ and then washed in digoxigenin detection buffer (DDB) $(33 \mathrm{mM}$ Tris, $33 \mathrm{mM} \mathrm{NaCl}, 50 \mathrm{mM}$ $\mathrm{MgCl}_{2}, \mathrm{pH}$ 9.5) for 5 min. The alkaline phosphatase color reaction was performed using $45 \mu \mathrm{l}(75 \mathrm{mg} / \mathrm{ml})$ nitroblue tetrazolium, $35 \mu \mathrm{l}(50 \mathrm{mg} / \mathrm{ml})$ bromo-4-chloro-3-indolyl phosphate, and $2.4 \mathrm{mg}$ freshly added levamisole in $10 \mathrm{ml}$ DDB. Sections were incubated $(1-4 \mathrm{~h})$ in the dark in a humidified box. The color reaction was terminated by washing in TE buffer (10 mM Tris, 1 mM EDTA, pH 8.0) (5 min) followed by mounting in Depex. Nonspecific hybridization was examined using slides that had been incubated with sense probe.

\section{Determination of the intracellular localization and transactivation potential of C2360}

Intracellular localization and transactivation potential were determined by visualization of eGFP-C2360 fusion proteins and by a mammalian two-hybrid assay, respectively. Truncated cDNA fragments of $\mathrm{C} 2360$ were cloned downstream of the eGFP coding region of the pEGFP-C2 (Clontech) or cloned downstream of the Gal4 DNA binding domain (GAL4-DBD)-encoding region into the $\mathrm{pM}$ vector of the Mammalian Matchmaker Two-Hybrid Assay Kit (Clontech). Primers are listed in Table 2. Plasmids were purified by anionexchange chromatography (Qiagen).

SGHPL5 cells [8] were transfected with the plasmids using Fugene 6 (Roche) according to the manufacturer's instructions. Expression analysis was performed $24 \mathrm{~h}$ after transfection (GFP) or $72 \mathrm{~h}$ after transfection (CAT assay). Intracellular localization of the GFP fusion proteins was performed by fixation of the cells in $4 \%$ paraformaldehyde in PBS, nuclear staining with Hoechst $33342(1 \mu \mathrm{g} / \mathrm{ml})$, and subsequent fluorescence microscopy using a triple bandpass filter. The presence of a transactivation domain on C2360 was measured (in triplicate) by cotransfection of the pM constructs with a pG5CAT reporter vector, containing a GAL4 promoter fragment upstream of the CAT enzyme. The CAT activity was measured using the CAT-ELISA kit (Roche). CAT levels were normalized using the total protein content of each sample. Positive controls were pM53, PVP16-T (p53 versus SV40 large T antigen protein-protein interaction), and pM3-VP16 (fusion protein of GAL4-DBD with the herpes simplex VP16 protein, which contains an activation domain). Negative controls were pM53, PVP16-CP (p53 versus polyomavirus coat protein interaction), and $\mathrm{pM}$, PVP16-T (empty $\mathrm{pM}$ vector versus SV40 large $\mathrm{T}$ antigen interaction).

\section{Computer structure analysis}

Secondary structure analysis was performed using the 3D-PSSM protein fold prediction program [9] to detect remote homology relationships between an uncharacterized protein sequence and proteins with known structures.

\section{Acknowledgments}

Dr. Charly Loke and Dr. Sue Hiby (Cambridge, UK) are kindly acknowledged for providing placenta tissues. Thea Tadema and Angelique Verlaan of the Department of Pathology at the VUMC are kindly acknowledged for providing adult tissues. Dr. Janneke de Vries and the participating coassistants of the department of Gynecology 
of the VUMC are kindly acknowledged for providing term placenta tissues. Dr. Kamlesh Madan and Dr. Aggie Nieuwint of the Department of Cytogenetics at the VUMC are kindly acknowledged for providing a continuous supply of chorionic villus samples. Dr. Renske D.M. Steenbergen is kindly thanked for critically reading the manuscript. The Dutch Cancer Society (KWF) funded this work, Grant VU-99-1993.

\section{References}

[1] J. Rossant, J.C. Cross, Nat. Rev. Genet. 2 (2001) 538-548.

[2] M. Hemberger, J.C. Cross, Trends Endocrinol. Metab. 12 (2001) $162-168$.

[3] M. Hemberger, J.C. Cross, H.H. Ropers, H. Lehrach, R. Fundele, H. Himmelbauer, Proc. Natl. Acad. Sci. USA 98 (2001) 13126-13131.

[4] T.S. Tanaka, S.A. Jaradat, M.K. Lim, G.J. Kargul, X. Wang, M.J. Grahovac, S. Pantano, Y. Sano, Y. Piao, R. Nagaraja, H. Doi, W.H. Wood III, K.G. Becker, M.S. Ko, Proc. Natl. Acad. Sci. USA 97 (2000) 9127-9132.

[5] M.S. Ko, T.A. Threat, X. Wang, J.H. Horton, Y. Cui, X. Wang, E. Pryor, J. Paris, J. Wells-Smith, J.R. Kitchen, L.B. Rowe, J. Eppig, T. Satoh, L. Brant, H. Fujiwara, S. Yotsumoto, H. Nakashima, Hum. Mol. Genet. 7 (1998) 1967-1978.

[6] M. Hemberger, H. Himmelbauer, J. Ruschmann, C. Zeitz, R. Fundele, Dev. Biol. 222 (2000) 158-169.

[7] P.M. Emmer, E.A. Steegers, H.M. Kerstens, J. Bulten, W.L. Nelen, K. Boer, I. Joosten, Hum. Reprod. 17 (2002) 1072-1080.

[8] M.Y. Choy, I.T. Manyonda, Hum. Reprod. 13 (1998) 2941-2949.

[9] L.A. Kelley, R.M. MacCallum, M.J. Sternberg, J. Mol. Biol. 299 (2000) 499-520.

[10] S.X. Cohen, M. Moulin, O. Schilling, W. Meyer-Klaucke, J. Schreiber, M. Wegner, C.W. Muller, FEBS Lett. 528 (2002) 95-100.

[11] R. Triepels, H.L. van den, J. Loeffen, R. Smeets, F. Trijbels, J. Smeitink, Hum. Genet. 103 (1998) 557-563.

[12] P. Barthe, L. Chiche, N. Declerck, M.A. Delsuc, J.F. Lefevre, T. Malliavin, J. Mispelter, M.H. Stern, J.M. Lhoste, C. Roumestand, J. Biomol. NMR 15 (1999) 271-288.
[13] P. Barthe, S. Rochette, C. Vita, C. Roumestand, Protein Sci. 9 (2000) 942-955.

[14] H. Demene, T. Ducat, P. Barthe, M.A. Delsuc, C. Roumestand, J. Biomol. NMR 22 (2002) 47-56.

[15] A.H. Charpentier, A.K. Bednarek, R.L. Daniel, K.A. Hawkins, K.J. Laflin, S. Gaddis, M.C. MacLeod, C.M. Aldaz, Cancer Res. 60 (2000) 5977-5983.

[16] U.K. Rout, S.A. Krawetz, D.R. Armant, Cell Calcium 22 (1997) 463-474.

[17] M.Y. Yang, Z. Wang, M. MacPherson, J.A. Dow, K. Kaiser, Genetics 154 (2000) 285-297.

[18] I. Maeda, Y. Kohara, M. Yamamoto, A. Sugimoto, Curr. Biol. 11 (2001) 171-176.

[19] R.S. Kamath, A.G. Fraser, Y. Dong, G. Poulin, R. Durbin, M. Gotta, A. Kanapin, N. Le Bot, S. Moreno, M. Sohrmann, D.P. Welchman, P. Zipperlen, J. Ahringer, Nature 421 (2003) 231-237.

[20] C. Jin, A.M. Myers, A. Tzagoloff, Curr. Genet. 31 (1997) 228-234.

[21] P. Fisch, A. Forster, P.D. Sherrington, M.J. Dyer, T.H. Rabbitts, Oncogene 8 (1993) 3271-3276.

[22] A. Madani, V. Choukroun, J. Soulier, V. Cacheux, J.F. Claisse, F. Valensi, S. Daliphard, B. Cazin, V. Levy, V. Leblond, M.T. Daniel, F. Sigaux, M.H. Stern, Blood 87 (1996) 1923-1927.

\section{Additional sources}

1. The $\mathrm{CHCH}$ protein family has been submitted to the PFAM database (entry in progress).

2. http:/www.sanger.ac.uk/Software/Pfam/index.shtml for description of the DUF657 domain.

3. The identity and functional classification of the sequenced clones of the human placental bed cDNA library will be available online (PDF file added).

4. http://www.wormbase.org for worm phenotypes.

5. http://sdb.bio.purdue.edu/fly/aimain/1aahome.htm for fly phenotypes.

6. Gene nomenclature of the $\mathrm{CHCH}$ domain containing genes that have been assigned recently (http://www. gene.ucl.ac.uk/nomenclature). 